Sexual Intercourse during Pregnancy and the Postpartum Period in Early Modern Spain ${ }^{1}$

\title{
Relaciones sexuales durante el embarazo y el puerperio en la España de la Temprana Edad Moderna
}

\author{
NINA KREMMEL ${ }^{2}$ \\ University of Vienna, Austria \\ nina.kremme1@univie.ac.at
}

\begin{abstract}
Queen Margaret of Austria (1584-1611) was married to King Felipe III for twelve years, of which she spent precisely half of the time pregnant. This case illustrates the relevance of a question which couples were repeatedly confronted with in Early Modern Spain: is lovemaking advantageous or harmful to the child's prenatal development? They might have been at a loss, given the hodgepodge of contradictory opinions from philosophical, moral, and medical authorities, in addition to common beliefs and lived experiences. The powerful Catholic Church declared sex as a marital duty, yet at the same time, she preached the virtue of chastity and that intercourse was only tolerable for social reproduction. Physicians were often indecisive, as any assessment would depend on the stage of pregnancy (not always easy to determine) and other factors. After delivery, puerperium constituted another transitory state which invited certain fears, but also a redefinition of the new mother's status and authority.
\end{abstract}

This brief study is based on manifold historical sources such as manuals, chronicles, and treatises, but also sayings and court cases. It aims to demonstrate the importance of a topic which is sensitive but highly relevant to the Spanish history of mentalities and has been overlooked for too long.

Keywords: pregnancy, sexual intercourse, childbirth, puerperium, Early Modern Spain

Resumen: El matrimonio de la reina Margarita de Austria (1548-1611) y Felipe III duró doce años, de los cuales ella pasó la mitad embaraza. Este caso ilustra la relevancia de una pregunta con la que las parejas se veían repetidamente confrontadas: ¿es favorable o perjudicial para el desarrollo prenatal del niño dormir juntos? No sería sorprendente que

\footnotetext{
${ }^{1}$ This publication is part of the Research Project The Interpretation of Childbirth in Early Modern Spain, funded by the FWF Austrian Science Fund, project number P 32263-G30. I would like to thank everyone involved in the project.

${ }^{2}$ Recipient of a DOC Fellowship of the Austrian Academy of Sciences at the Institute of Romance Studies, Vienna.
}

Recibido: 19 de diciembre de 2018; aceptado: 10 de octubre de 2019; publicado: 31 de marzo de 2020.

Revista Historia Autónoma, 16 (2020), pp. 71-81

e-ISSN: 2254-8726; https://doi.org/10.15366/rha2020.16.004 
estuvieran desorientados, dada la multitud de opiniones contradictorias de filósofos, moralistas y médicos, así como creencias comunes y experiencias vividas. Por ejemplo, la poderosa Iglesia Católica declaró el sexo como débito conyugal, pero al mismo tiempo profesó la virtud de la abstinencia y que el concúbito sería solo lícito para la reproducción social. Los médicos se quedaron indecisos, pues cualquier estimación dependía del estado del embarazo (no siempre fácil de determinar) y otros factores. Después del parto, el puerperio constituyó otro estado de transición que implicó preocupaciones, pero también una redefinición del estado social y la autoridad de la nueva madre. Este breve estudio está basado en diversas fuentes históricas como manuales, crónicas y tratados, refranes y casos legales. Su objetivo es ilustrar la importancia de un tema delicado, pero sumamente importante para las mentalidades áureas, que fue pasado por alto durante demasiado tiempo.

Palabras clave: embarazo, coito, parto, puerperio, Siglo de Oro

\section{Biology: Forming the Fetus vs Fear of Superfetation}

Historically, at least two beliefs about the role of semen during early pregnancy have persisted for centuries and within different cultures. On the one hand, doctors warned about the possibility of superfetation: impregnation with a second fetus while the woman is already carrying a child in another stage of pregnancy. On the other hand, people believed that semen would continue to form and nourish the fetus in the womb.

When Aristotle and Hippocrates first discussed the rare phenomenon of superfetation in women, they did not associate it with social stigma, but attributed it to biological factors. According to Zuccolin, they argued that a second fertilization was only possible when the cervix had not fully closed after the first conception ${ }^{3}$. The philosophers' idea of superfetation is relevant to our context because it was being discussed ever since, also by Early Modern Spanish authors. In 1616, for instance, the Spanish physician Juan Sorapán de Rieros (1572-1638) cleared away any doubts about the possibility of superfetation, explaining with Galen that the uterus closes tightly as soon as a woman is pregnant and that midwives use this aspect as a sign for determining pregnancy ${ }^{4}$. In that regard, Sorapán described the anecdotal example of Julia

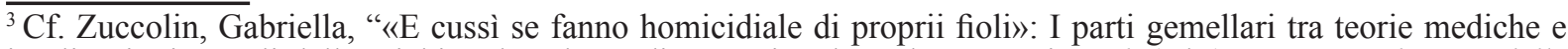
implicazioni morali dall antichità al tardo medioevo", in Alessndro Foscati et al. (eds.): Nascere: Il parto della tarda antichità all'età moderna, Bologna, Il Mulino, 2017, p. 82.

${ }^{4}$ Curiously though, the contemporary Spanish physician Juan Alonso de Fontecha wrote in an obstetric treatise of 1606 (Diez privilegios para mujeres preñadas) that superfetation did occur and therefore he wanted to give instructions about how women could tell whether, after giving birth, there was another creature left in the womb. However, I think he probably did not distinguish superfetation from normal twin births. As seen in Savonarola, one frequent problem is the lumping together of regular twin pregnancies and superfetation, due to unclear definitions. Cf. Alonso de los Ruices y Fontecha, Juan, Diez previlegios para mujeres preñadas, Alcalá de Henares, Luis Martínez Grande, 1606, fol. 149r.
} 
the Elder - Augustus's scandalous daughter — who is said to have known (by her husband), she could give herself to her lovers without risking an illegitimate child 5 .

However, the birth of twins posed an argumentative problem to the question of superfetation, especially because, whenever twins occurred in classical sources, it was attributed to adultery, be that the case of Castor and Pollux or Heracles and Iphicles. Moreover, twins are often different in size and therefore appear to be in different stages of development when they are born ${ }^{6}$. So, by the Middle Ages, women who gave birth to twins aroused certain suspicions and they were held responsible not biologically, but ethically and morally ${ }^{7}$.

This is made obvious by the Italian physician Giovanni Michele Savonarola who wrote the first gynecological treatise in the vernacular tongue, De regimine praegnantium, in the first half of the $15^{\text {th }}$ century. He claimed that the uterine orifice of a pregnant woman would only open - and hence allow superfetation, which he did not clearly distinguish from twin pregnancy - due to a particularly strong sexual drive and the sensation of lust. Unlike any other living beings (except for mares), only women engaged in intercourse during pregnancy, and just like Albertus Magnus, Savonarola maintained that during this time women would be at their most voluptuous ${ }^{8}$.

A pregnant woman's vehement rejection of intercourse, on the contrary, was associated with her carrying a male child, according to several authors, from the Persian physician Rasis (854-925 CE) to the Spaniards Luis Lobera de Ávila9 and Alonso de Fontecha ${ }^{10}$. This somewhat ridiculous idea hardly comes as a surprise to those who know to what extent baby boys were generally preferred over girls, and therefore a good and uncomplicated pregnancy was suggestive of a male child ${ }^{11}$.

After all, once the child is conceived, what could sex be good for anyway? Let us look at the other side of the coin. The father could model the "bulky mass" in the mother's womb with his semen. Through intercourse, he could shape his future child and make it look more like him. This is one reason why many Occidental physicians tolerated sexual relationships during pregnancy up to the beginning of the $18^{\text {th }}$ century, according to Gélis ${ }^{12}$. Semen was also believed

\footnotetext{
${ }^{5}$ Cf. Sorapán de Rieros, Juan, Medicina española contenida en proverbios vulgares de nuestra lengua..., s.1., Marín Fernández Zambrano, 1616, pp. 16-18.

${ }^{6} \mathrm{Cf}$. Gélis, Jacques, L'arbre et le fruit: la naissance dans l'Occident moderne (XVIe- XIXe siècle), Paris, Fayard, 1984, p. 373.

${ }^{7}$ Cf. Zuccolin, Gabriella, "E cussí se fanno... op. cit., 2017, pp. 82f, 89.

${ }^{8}$ Ibidem, pp. 89-92. In $16^{\text {th }}$ Century France physicians as Laurent Joubert $(1529-1582)$ wrote the same. Quoted in Gélis, Jacques, L'arbre et le... op. cit, p. 157, footnote 89. Furthermore, Savonarola even advised husbands that pregnant wives should not be too well-fed because that would enhance their sexual desire even more, and consequently the risk of superfetation.

${ }_{9}^{9}$ In his Libro del regimiento de la salud (1530), quoted in Hernández Bermejo, María A., "La imagen de la mujer en la literatura moral y religiosa de los siglos XVI y XVII", in Norba: Revista de Historia, 8-9 (1987-1988), p. 177. See also Lobera de Ávila, Luis, Libro del regimiento de la salud y de la esterilidad de los hombres y mujeres..., Valladolid, Sebastián Martínez, 1551, fols. XLVII (verso)-XLVIII.

${ }^{10}$ Alonso, Juan, Diez privilegios... op. cit., fol. 28v.

${ }^{11}$ Cf. Gélis, Jacques, L'arbre et le... op. cit., pp. 160-162.

${ }^{12}$ Ibídem, pp. 101, 157.
} 
to nourish the fetus, in the same manner as the mother's blood: where else could the absent menses flow if not to the unborn child?

The outlined ideas were widespread across different cultures throughout the world and persisted for centuries. The fact that they are not specifically characteristic for Early Modern Spain shows that some concepts related to the very beginning of human life are often universal rather than limited to a certain culture or historical period. For instance, Maurice Godelier, who studied the Baruya people of Papua New Guinea in the 1960s, reported that the Baruya believed that the father's semen was an important nourishment for his unborn child ${ }^{13}$. The same occurred with the indigenous Nahuas in the $16^{\text {th }}$ century, and it is still true of some Mayan groups nowadays: they view pregnancy as a shared responsibility, part of which involves frequent sex during the first months ${ }^{14}$.

\section{Moral: Marital Duty vs the Virtue of Chastity}

What about the moral implications? The influential Catholic Church's stance towards sex during pregnancy was somewhat contradictory. Whereas coitus was considered an important conjugal duty, it was simultaneously condemned when the possibility of procreation was precluded, as is the case during pregnancy. These two key aspects shall now be presented in greater detail.

The Old Testament "sings the praises of physical love and in no way condemns pleasure as such" ${ }^{15}$. Even though I personally would not go as far as Flandrin here, it is true that being "fruitful and [multiplying]" (Genesis 1:28) was not yet bound to restrictions such as marriage or monogamy. In the New Testament, procreation was not the only and sole purpose of marriage. St. Paul defined intramarital intercourse as a remedy for concupiscence; in 1 Corinthians 7:3, he simply wrote: "The husband should fulfill his marital duty to his wife, and likewise the wife to her husband". In the work On the Good of Marriage, Augustine suggested that "for the sake of begetting" there is no fault at all in intercourse, whereas sex among married people motivated by lust is a venial, but not a mortal sin. In that case, only the person who seduces their partner sins venially, whereas the other only fulfills his or her duty. Augustine's influence persisted

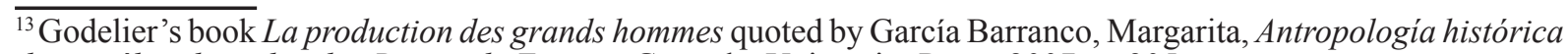
de una élite de poder: las Reinas de España, Granada, University Press, 2007, p. 305.

${ }^{14}$ Alcántara Rojas, Berenice, "Miquizpan. El momento del parto, un momento de muerte. Prácticas alrededor del embarazo y parto entre nahuas y mayas del Posclásico", in Estudios Mesoamericanos, 2 (2000), p. 38.

${ }^{15}$ Flandrin, Jean-Louis, Sex in the Western World: The Development of Attitudes and Behaviour, Chur, Harwood, 1991, p. 90.
} 
and his doctrine was still very present from the $13^{\text {th }}$ to $15^{\text {th }}$ centuries ${ }^{16}$, even though theologians such as Albert the Great and Thomas Aquinas "accepted that couples could have intercourse for reasons other than procreation" 17 .

The development of this religious discourse is important for our purpose for the obvious reason that Spain was a stronghold of Catholic doctrine in Europe. And yet, a discrepancy between the theoretical, written Church law and lived religion is made evident in a book on marriage written by one of the most respected moral theologists in Spain, Tomás Sánchez de Ávila (1550-1610). The casuist addressed whether coitus is licit during pregnancy (between spouses, of course) in the ninth book of his Controversias del Santo Sacramento del Matrimonio. He magnanimously declared that it is not a venial sin, as long as it is moderate, as he cannot find any prohibitions. More interestingly, he added that there is no need to make marriage the heavy burden that it might become, were they to refrain from coitus during pregnancy, because the wife is "almost always" pregnant ${ }^{18}$.

Despite all this, chastity was incontestably held to be the highest virtue. The immaculate Virgin Mary, the incarnation of purity and chastity, was certainly the most venerated saint in Early Modern Spain. A detail concerning her visitation to Elizabeth caught my attention and makes me wonder: might one (secondary) purpose of this visit have been to ensure the pregnant Elizabeth's chastity? Three things lead me to put forward this adventurous hypothesis.

Firstly, in Luke 1:24-25, it says that after Elizabeth had conceived, she remained in seclusion for five months. Considering that infertility was seen as a curse and disgrace, from which pregnancy meant a relief, this seems a little surprising. Several theologists and scholars have established theories about Elizabeth's "hiding"19, but as far as I can tell, none of these included the possibility that she might have wanted to thank and praise the Lord through the noble virtue of chastity ${ }^{20}$.

Secondly, Mary visited Elizabeth when she was in her sixth month and remained with her for the next three months, i.e., until immediately before Elizabeth gave birth (Luke 1:56). Therefore, throughout her entire pregnancy, Elizabeth was either secluded or in Mary's company. The Virgin blessed both the baby and the mother, and brought them Divine Grace, but her person was also and always inseparably connected with chastity.

\footnotetext{
${ }^{16}$ Cf. Genovesi, Vincent J., In Pursuit of Love: Catholic Morality and Human Sexuality, Minnesota, The Liturgical Press, 1996, p. 182.

${ }^{17}$ Flandrin, Jean-Louis, Sex in the Western World... op. cit., 1991, p. 181.

${ }^{18} \mathrm{Cf}$. Sánchez de Ávila, Tomás, Controversias del Santo Sacramento del Matrimonio. Traducción del latín, edición de Tomás Rey, Madrid, Imprenta Popular, 1887, pp. 143-149, controversy 22, n. 6.: "Digo en segundo lugar que es muy probable que no haya pecado venial pagando el débito en estado de preñez, porque ninguna prohibición encuentro; y donde no hay necesidad no deben multiplicarse las culpas, mucho más cuando el matrimonio sería entonces carga pesada por encontrarse casi siempre la mujer preñada y los cónyuges deberían abstenerse del coito o tendrían que ser reos de innumerables pecados veniales. [...] que no ha de prohibirse del todo el coito en tiempo de preñez, pero sin exceder del modo y temperancia."

${ }^{19}$ See some of the authors referred in Strelan, Rick, "Elizabeth, are you hiding?", in Neotestamentica, vol. 37, 1 (2003), pp. 87-95.

${ }^{20}$ Elizabeth's and Zachary's advanced age does not exclude this possibility for me.
} 
Thirdly, Mary was "an example of chastity to all” who surrounded or simply looked upon her, as Alphonsus Liguori affirms in his Glories of Mary (1750). The Saint's mere presence inspired everybody with thoughts of purity and encouraged them to aspire to chastity ${ }^{21}$. This finding is interesting in the Spanish context, because as Juan de Ávila (1499-1569) — the "Apostle of Andalusia" - put it: "Many temptations against chastity have been overcome solely by devotion to the immaculate Virgin"22.

It has been a common practice in Europe since the Medieval Ages $^{23}$ for pregnant women to seek protection, assurance, and strength from the Virgin who gave birth without pain. However, her veneration was particularly strong in the early modern period in Spain ${ }^{24}$. Consequently, it might be an interesting approach to consider the Virgin not only as a protective force but also as an incentive for maintaining chastity during pregnancy.

\section{Medicine: Risk of Miscarriage vs Preparation and Labor Induction}

Alongside theologians and moralists, physicians also had advice and concerns to share in relation to intercourse during pregnancy. Some warned against it because they connected it with risks to the child and with miscarriage, especially in earlier months; others thought it would be a good preparation for childbirth and even cited it as a possible method for labor induction. Moreover, these advices changed with the different stages of pregnancy and the whole issue was located in a sort of a grey zone, where statements were made cautiously and doubts could never fully be refuted.

Even so, the attributed negative effects tended to occupy Spanish physicians more than the possible benefits, which is why some of these concerns will be outlined first. In an early chapter on how to conserve pregnancy (De conservatione pregnantium) from 1530, the abovementioned physician Lobera de Ávila explained that the future mother should avoid coitus because it would restrict and oppress the baby in the womb ${ }^{25}$. In 1580, Francisco Núñez de

\footnotetext{
${ }^{21}$ Quoting, respectively, Sophronius, St. Denis the Carthusian, and St. Thomas. Cf. Liguori, Alfonso Maria de, The Glories of Mary, New York, Kenedy \& Sons, 1888, pp. $427 \mathrm{f}$.

${ }^{22}$ Cf. Ibídem, p. 628.

${ }^{23}$ See Gélis, Jacques, L'arbre et le... op. cit., p. 137, also for more information on Marian devotion in France.

${ }^{24}$ The ways in which Mary was worshipped is best visible in studies concerning the Spanish Queens, because their cases are the best documented ones. See e.g. Carlos Varona, María Cruz de, "Entre el riesgo y la necesidad. Embarazo, alumbramiento y culto a la Virgen en los espacios femeninos del Alcázar de Madrid (s. XVII)", en Arenal, vol. 13, 2 (2006), pp. 276-290, and Cobo Delgado, Gemma, "Su majestad está de parto. Cultura material y visual entorno a la fecundidad de Margarita de Austria", in Almarcha Núñez-Herrador, María Esther et al., El Greco en su IV centenario. Patrimonio Hispánico y diálogo intercultural, Cuenca, Universidad de Castilla-La Mancha, 2016, pp. 792-802.

${ }^{25}$ Lobera de Avila, Luis, Libro del regimiento... op. cit., fol. XLI (verso): "fugiant coitum propter foetum et compressionem".
} 
Coria also advised against it in his Libro del parto humano, without offering an explanation, besides quoting Hippocrates's statement that labor would be easy if intercourse were shunned ${ }^{26}$.

In his obstetric treatise on pregnant women's privileges from 1606, the physician Alonso de Fontecha dedicated eight pages ${ }^{27}$ to the question of whether and why they might turn their husband's erotic requests down. He begins by saying that many major authors, including Rasis and Avicenna, but also Greeks, counted intercourse among the most common causes of miscarriage. He cites several reasons for this assumption, among which is the already mentioned physical (internal and external) pressure on the womb and the baby. Another concern was that the sexual act might provoke a premature dilatation or an opening of the uterus, which could result in the expulsion of the fetus. But even outside of this worst-case scenario, other disadvantageous effects could occur. Alonso's biggest concern was for pregnant women to preserve their energy for the crucial moment of labor; therefore, he claimed the venereal act to be nothing but a waste of virtue and energy, because on each occasion - according to Hippocrates - the body emits and loses some of its warmth, spirit, and substantial liquid. Sex, the Spaniard argues, is generally tiring, causing headaches, insomnia, and pain to the kidneys and bladder, weakening the stomach and doing "countless further harms"

Moreover, certain moralists and theologists such as Francisco de Osuna, Simón de Salazar or Diego de Cabranes also referred to the medical dangers of intercourse to underline their point, as Jesús Usunáriz demonstrates in his article about the Golden Age father's role during pregnancy $^{29}$.

All of those concerns are valid and did indeed prevail among the majority of physicians; yet, certain contrasting voices that praised the benefits of lovemaking are just as relevant and should not be omitted. Even after the early modern period, in 1827, the physician Pascual Mora asked: “¿Qué confianza, pues, se podrá tener en la cópula que, según Aristóteles, vuelve el parto más fácil en las mujeres cuando hacen uso antes de parir?" ${ }^{30}$. In this case, it is not clear whether Mora refers to the period immediately before giving birth, or to the months preceding it. Looking at early modern Spanish sources, both notions existed.

Regarding the months before childbirth, Gonzalo Correas wrote the following in his collection of proverbs and sayings from 1627: "A la preñada se ha de dar hasta que para, y a la parida cada día, y a la que no pare hasta hacerla concebir para que venga a parir". He also added: "Entiende lo del ayuntamiento de los casados; y en prueba de ello me dijo una honrada

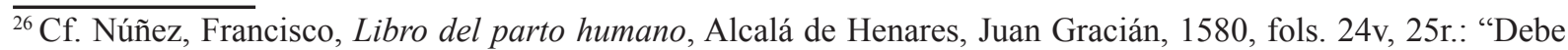
también la preñada huir lo más que pudiere del ayuntamiento del varón, pues dice Hipócrates: Mulier praegnans si non utatur coitu facilius a partu liberatur."

${ }^{27} \mathrm{Cf}$. Alonso, Juan, Diez privilegios ... op. cit., fols. 74v-78r.

${ }^{28}$ Ibidem, fol. $77 \mathrm{v}$.

${ }^{29}$ Cf. Usunáriz, Jesús M., "El padre ante el parto en la España de los siglos XVı y xvII", in Hipogrifo, vol. 6, 1 (2018), pp. 489f. https://doi.org/10.13035/h.2018.06.01.34

${ }^{30}$ Mora, Pascual, El hombre en la primera época de su vida, vol. 1, Madrid, Francisco Martínez Dávila, 1872, p. 72. "Can we trust Aristotle when he says that copulation makes childbirth easier for women when they make use of it before giving birth?" [Author's translation].
} 
matrona que enviudando recién preñada tuvo recio parto por faltarla la junta de marido, lo cual no la sucedió en otros partos antes" ${ }^{31}$. This entry contains two very revealing pieces of information. First, the context: a saying usually comes from popular opinions and indicates that what is said is considered common and accepted as given by many speakers. Second, the fact that an honorable midwife told the author how difficult a recent widow's delivery was compared to her prior deliveries, as a result of the missing intercourse. Both points suggest that, from a socio-cultural point of view, sex during late pregnancy was nothing unusual and was even believed to be helpful — despite the "scientific" warnings described above-. Again, this shows that scholarly culture could differ considerably from popular praxis.

As for copulation immediately before delivery, it could be considered a questionable technique of labor induction. "Reading the doctors, I saw several times that when the woman is close to giving birth, she shall sleep with her husband, because the coitus lubricates her uterus", wrote the physician Damián Carbón in 1541, in relation to factors that contributed to a good delivery ${ }^{32}$. I think it is noteworthy that he does not dare to give this advice himself, but that he chooses to refer to other doctors as intermediaries, which shows how sensitive this topic was. Nevertheless, this indicates that, in some parts of Spain, intercourse was used to initiate labor, because it was thought to ease the delivery ${ }^{33}$. The Spanish ethnologist Castillo de Lucas pointed out that in rural areas the midwives would encourage the husband to sleep with his wife when the delivery was proving difficult, in order to "open the uterine orifice" ${ }^{34}$. Unfortunately, this practice did not always go well, as the following enforcement proceedings suggest:

a) Ejecutoria del pleito litigado por Sebastián González, vecino de Rincón de Soto (La Rioja), con Tomás de Vega, vecino de Calahorra (La Rioja), sobre estupro y muerte de su hija durante el parto. $1628^{35}$

b) Real provisión compulsoria a petición de Antón Escudero, vecino de Villabrágima (Valladolid), con el fiscal del rey, sobre estupro y hacer perder mucha sangre en el parto de Magdalena Barroso, criada de Antón Escudero, ayudándose para tal fin de María de Collantes, comadrona. $1574^{36}$

In the first case, from 1628, a woman apparently died during delivery and her father blames Tomás de Vega who seemingly forced himself upon her while she was giving birth. The second case, from 1574, is more complex, because it involves a midwife, María de Collantes.

\footnotetext{
${ }^{31}$ Cf. Correas, Gonzalo, Vocabulario de refranes y frases proverbiales y otras fórmulas comunes de la lengua castellana ..., ed. Miguel Mir, Madrid, Jaime Ratés, 1906, p. 4.

${ }^{32}$ Carbón, Damián, Libro del arte de las comadres o madrinas y del regimiento de las preñadas y paridas y de los niños, Mallorca, Hernando de Cansoles, 1541, fol. 36v: "Muchas veces he leído en los doctores que como la mujer será propincua al parir que use con su marido; y esto es conforme a la razón, porque el coito hace la madre lubrica." ${ }^{33}$ Cf. Sánchez Arcas, Ruperto, "Creencias, supersticiones y mitos que fueron considerados inhibidores y facilitadores de la parturición", in Medicina \& Historia, 72 (1970), pp. 2-16, p.15. The same is true for sternutation or vomiting, which were provoked for this purpose. Cf. Reche, Oliver, "Plantas y remedios usados tradicionalmente en la asistencia al parto", in Matronas profesión, vol. 1, 1 (2000), p. 34.

${ }^{34} \mathrm{Cf}$. Castillo de Lucas, Antonio, Folkmedicin a: Medicina popular, folklore médico, etnomedicina ..., Madrid, Dossat, 1958, pp. 445f.

${ }^{35}$ Archivo de la Real Chancillería de Valladolid [from now on ARC], Registro de Ejecutorias, Caja $2484,8$.

${ }^{36}$ ARC, Registro de Ejecutorias, Caja 1296, 46.
} 
The mother is Antón Escudero's maidservant, Magdalena Barroso, who became victim of "rape" and therefore lost a lot of blood during delivery. In the text it says that the midwife had given Antonio the order to do so and that Magdalena finally suffered a stillbirth ${ }^{37}$.

\section{Puerperium}

A series of moral, medical, and social aspects connected to childbirth did not end after a successful delivery. In this part I will explore what puerperium meant for a new mother and her husband. In Early Modern Spain, puerperium initiated an undetermined period in which the mother was focused on her recovery. It ended with the celebration of the so-called misa the purificación, a catholic "purification" ceremony ${ }^{38}$. Looking at several sources, I will elucidate whether sexual intercourse was "allowed" during this time.

From the moral point of view, Sánchez de Ávila's treatise offers, again, an interesting insight. He explained that the Old Testament prescriptions of Leviticus no longer had to be followed. That book claimed that women who had given birth were impure for forty days if they bore a boy, and for eighty days if they had a girl. During that time, they were not allowed to enter the temple or church and were considered "just as unclean" as during their period, when sex was forbidden (Lev. 12: 1-8). According to Sánchez de Ávila, by the end of the $16^{\text {th }}$ century, this proscription was no longer an obligation, due to its mere ceremonial character ${ }^{39}$. However, the fact that he refuted the Old Testament shows the enduring influence of the latter on the Spanish society.

Even so, physicians remained skeptical. Writing about the midwife's authority, Alonso de Fontecha remarked that the midwife could insist that the new mother would not accept physically demanding work and would not have intercourse ${ }^{40}$. Núñez described what "usually happens" when a mother sleeps with her husband too early: the created heat risks causing an inflammation of the pubic area and difficulty urinating. Despite this, the worst possible

\footnotetext{
$\overline{37}$ Antonio was considered "culpante en haber tratado y dado orden con María de Collantes, comadre [...] que hiciese malparir a Magdalena Barrosa su criada [...] y haberla hecho sangrar y estuprándola." Cf. Ibídem, figure $\mathrm{n}^{\circ} 2$.

${ }^{38}$ Cf. Usunáriz, Jesús M., "El padre... op. cit., p. 494. For an anthropological approach, see Douglas, Mary, Purity and Danger: An Analysis of Concepts of Pollution and Taboo, London, Routledge \& Kegan Paul, 1966; and Van Gennep, Arnold, Rites de Passage, Chicago, University of Chicago Press, 1909. A woman in childbed is definitely in a transitional state, which, according to those authors, implies a certain danger, "simply because transition is neither one state nor the next $[\ldots]$. The person who must pass from one to another is himself in danger and emanates danger to others. The danger is controlled by ritual which precisely separates him from his old status, segregates him for a time and then publicly declares his entry to this new status". This is exactly what happens with new mothers after childbed. Douglas, Mary, Purity and Danger... op. cit., p. 96.

${ }^{39}$ Cf. Sánchez de Ávila, Tomás, Controversias... op. cit., pp. 143-149, controversy 22, n. 8.

${ }^{40}$ Cf. Alonso, Juan, Diez privilegios... op. cit., fol. 159v. "Tendrá también la comadre autoridad sin llamar médico para ordenarle a la parida un buen regimiento y manera de vivir: [...] y así les podrán encomendar se guarden de trabajo donde hagan fuerza de consideración, traerse el vientre con violencia, tener junta durante el puerperio".
} 
consequence was thought to be a "prolapse", which means the uterus turning inside out or "falling out" of the female body ${ }^{41}$.

When the epistolographer Jerónimo de Barrionuevo described Queen Mariana of Austria, in childbed, suffering from an erysipelas on her leg and frequent vomiting, he conjectured that "she must have slept with the king" have been almost two weeks after Mariana had given birth to the Infanta Maria Ambrosia on December $7^{\text {th }}$ of 1655 , because the entry right before her illness is from December $18^{\text {th }}$. To me, the fact that the author blames the king's impatience for his wife's issues is an astonishing piece of information, which leads me to think that Barrionuevo either conveys a physician's opinion on the case, or that it must have been a popular and common belief that intercourse caused adverse effects when it happened too early in childbed.

On a social level, the woman in childbed has a very special position within her family and surrounding society. The Spanish woman in childbed is not primarily an impure woman, Usunáriz reasons, but rather a woman who needs a break from her normal daily life — which makes the whole idea of "impurity" nothing but a pretext, an excuse to conserve the mother's health and, also, to keep her husband from concupiscent thoughts and acts. During this time, she is freed from any duties she usually has towards her husband, be that the marital debt or physical work. Thereby, she temporarily escapes the patriarchal world ${ }^{43}$.

\section{Conclusion}

The contribution of this study has been to illustrate some aspects of how sexual relationships were handled during and after pregnancy in Early Modern Spain. The question of whether intercourse was compatible with the transitory, often risky state of pregnancy, was highly sensitive and controversial, which makes it a particularly interesting research topic. The most important and revealing findings shall be summarized below.

Those nine months of expectation were associated with many hopes and doubts, as a look at several sources suggests. With regard to what would now be considered biological aspects, at least two opposing notions tended to be historically strong. On the one hand, semen was believed to nourish and form the fetus, just like the mother's blood, which therefore suggests

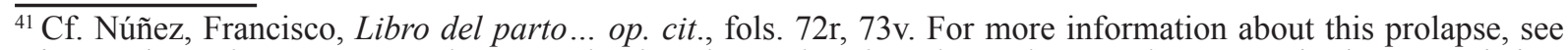
King, Helen, The One-Sex Body on Trial: The Classical and Early Modern Evidence, London/NY, Routledge, 2016, pp. 122f. https://doi.org/10.4324/9781315555027

${ }^{42}$ Barrionuevo, Jerónimo de, Avisos (1654-1658), vol. 2, Madrid, Tello, 1892, p. 244. "Dióle a la reina una erisipela en una pierna, que aunque es de alcorza, ya el mal todo lo anda, y juntamente tantos gómitos que ha haber dormido con el rey, se tuviera por preñado. No podía retener nada. Aplicáronsele remedios gallardos. Está mejor."

${ }^{43}$ Usunáriz, Jesús M., "El padre... op. cit., pp. $494 \mathrm{f}$.
} 
that repeated intercourse is good for the child's development. On the other hand, philosophers often discussed the phenomenon of superfetation, much feared despite its extremely rare occurrence in the human species. The introduction of another fetus in the womb, at a different stage of development, would cause both creatures to receive less nourishment and make the survival of both very unlikely.

The moral and theological view of the topic might seem even more confusing at first sight. Theoretically, intercourse was a marital duty which should not be denied. Theoretically, sleeping together was also officially a venial (though not deadly) sin, when reproduction was precluded. However, certain moralists of the late $16^{\text {th }}$ century such as Tomás Sánchez de Ávila were well aware that those traditional, old proscriptions were difficult to reconcile with the early modern reality. They understood that, as women were "almost always pregnant", a moral prohibition of sexual relationships during that time would only turn marriage and sharing a bed into a burden.

The Catholic emphasis on chastity and the virtues of Mary is another characteristic aspect of the Spanish Golden Age. Mary was probably the most venerated saint, especially among pregnant women, but she also inspired the resisting of carnal temptation. I have established the bold hypothesis that Mary's visitation to Elizabeth might have also contributed to Elizabeth's chastity, which would have been one way to thank God for the grace she had received. This assumption is based on Elizabeth's self-inflicted reclusion during the first five months of her pregnancy, directly followed by the Virgin's presence until Elizabeth gave birth.

Reading the physicians' manuals gives an idea of what doctors were worried about: the sexual act might put too much pressure on the womb and oppress the baby in the womb. In the later stages of pregnancy, it might even cause a premature delivery, which in the worst case could result in the child's death. Yet, with moderation and care, intercourse during pregnancy might just as well contribute to an easier birth, according to sources from Aristotle to midwives and popular sayings. Some even went so far as to consider it a possible measure to induce labor: a risky decision that sometimes had nefarious consequences, as shown in two court cases.

I have also looked into some of the moral, medical, and social implications of childbed with regard to the new mother and her husband. Morally, the Old Testamentary restrictions were no longer considered binding, as the idea that a woman is impure after childbirth had tended to become obsolete. Despite this "green light", physicians remained skeptical. They thought that a too early intercourse after giving birth could cause a prolapse of the uterus, alongside other rather uncomfortable symptoms. It is therefore no wonder that the chronicler Barrionuevo blamed the King's love for the Queen's sickness and rash two weeks after she had given birth. Physicians and midwives both allowed and advised women in childbed to turn their husbands down: a circumstance that turned the usual balance of power upside down for a certain period and gave the new mothers time off from all kinds of responsibilities. 